\title{
Employment of Somatic Embryogenesis as a Tool for Rescuing Imperiled Narcissus tazetta L. Growing Wild in Jordanian Environment.
}

\author{
Tamara M. Al-Zghoul ${ }^{1}$, Rida A. Shibli ${ }^{1,{ }^{*}}$, Tamara S. Qudah ${ }^{2}$, Reham W. Tahtamouni ${ }^{3}$, \\ Nasab Rawshdeh ${ }^{4}$ \\ ${ }^{1}$ Department of Horticulture and Agronomy, Faculty of Agriculture, University of Jordan, Amman, Jordan, ${ }^{2}$ Hamdi Mango Center for \\ Scientific Research (HMCSR), University of Jordan, Amman, Jordan, ${ }^{3}$ Department of Biotechnology, Faculty of Agricultural technology, Al \\ Balqa-Applied University, Salt, Jordan. ${ }^{4}$ National Center for Agricultural Research and Extension (NCARE).
}

Received: September 3, 2020; Revised: November 4, 2020; Accepted: November 24, 2020

\begin{abstract}
Somatic embryogenesis was used as a tool for micropropagation of wild Narcissus tazetta plants exposing to overcollection and rapidly changed environmental conditions. In the growth regulators experiment, somatic embryogenesis was successfully induced in all treatments except for explants grown in the control treatment (Murashig and Skoog (MS) hormone-free medium). Meanwhile, the highest value for the number of somatic embryos/ callus segment (441) was obtained into MS media supplemented with $0.2 \mathrm{mg} \mathrm{l}^{-1}$ 6-(gamma, gamma- Dimethylallylamino) purine (2iP) under dark conditions. Moreover, sucrose at $30 \mathrm{~g} \mathrm{~L}^{-1}$ was the best sugar source resulting in higher number of somatic embryos compared to the other sugar treatments. The highest shoot development rate from somatic embryos was (191.99/ non-embryonic calli segment) recorded in cultures grown on MS media plus $0.5 \mathrm{mg} \mathrm{l}^{-1} 2 \mathrm{iP}$. Maximum bulbet size $(1.6 \mathrm{~cm}$ diameter) was recorded in plantlets kept onto hormone-free MS hormone free media for 6 weeks before acclimatization, while less durations resulted in smaller bulbet size. Well developed in vitro plantlets were acclimatized successfully with high survival percentage of (95\%). The acclimatized plants were normal and did not show any morphological abnormalities.
\end{abstract}

Keywords: Callus, Embryogenesis, Narcissus tazetta, Somatic embryo.

\section{Introduction}

Narcissus tazetta is a wild ornamental plant that grows naturally in the hills and mountainous rocky grounds of Jordan. It is known by the local community as (Narjes Baladi). It has an important ornamental value due to its white-cream with orange crown flowers and its distinctive odor (Al-Eisawi, 1998). In addition, many wild plants in Jordan had been reported for their medicinal activities (Alenizi et al., 2020; Al Qudah, 2020; Tahtamouni et al., 2016). Also, Narcissus tazetta was reported recently in many research articles as a natural source of galantamine (GAL) which has been prescribed for treatment of Alzheimer's disease (Bores and Kosley, 1996; Khonakdari et al., 2020). Because of overexploitation through uprooting and continuous removal of the plants, natural habitat destruction, climate change, and increasing demands on this plant for both ornamental and medicinal values (Alenizi et al., 2020), the wild $N$. tazetta populations in Jordan are exposed to extinction (RBG, 2016). Propagation of this valuable genetic resource is imperative for its survival and continuity. Unfortunately, $N$. tazetta propagation through vegetative methods by chipping and twin scales is not efficient due to its slow propagation (Stone, 1973; Stone et al., 1977). Propagation of $N$. tazetta can help in conserving this valuable plant from extinction. In vitro development techniques including somatic embryogenesis are important and easy methods of vegetative multiplication, and they have the advantage of rapid multiplication (Shibli et al., 2012). High numbers of genetically uniform plants can be cultured from a single plant by using those techniques (Al Qudah et al., 2011; Shibli et al., 2018). Somatic embryogenesis is one of the basic tools widely used in plant biotechnology and in vitro development research. It is useful for micropropagation and production of transgenic plants, which can be used for producing fully transformed plants after mutagenesis or gene transfer (Mostafa et al. 2010). Somatic embryos can be produced in high frequencies, but maturation and plant development are still a difficult task, requiring optimization of medium and environmental conditions (Kumar et al., 2013; Shibli et al., 2012). In reviewing the literature, until now, there were no reports on the in vitro development via somatic embryogenesis of the valuable wild Jordanian $N$. tazzeta L. Thus, this study was carried out to develop a protocol for in vitro massive propagation via somatic embryogenesis and ex vitro acclimatization of $N$. tazetta L, hoping that this approach might contribute to its sustainability.

\footnotetext{
* Corresponding author e-mail: r.shibli@ju.edu.jo.
} 


\section{Materials and methods}

\subsection{Plant material}

Bulbs of Narcissus tazetta L. were collected from Ajloun- Kufranja during December of 2014 (N 32.25006 ${ }^{\circ}$, E $35,652336^{\circ}$ ) at $210 \mathrm{~m}$ above sea level (Fig. 1). The experiments were held at the plant biotechnology laboratories at Hamdi Mango Center/ Faculty of Agriculture, The University of Jordan, (Amman-Jordan).

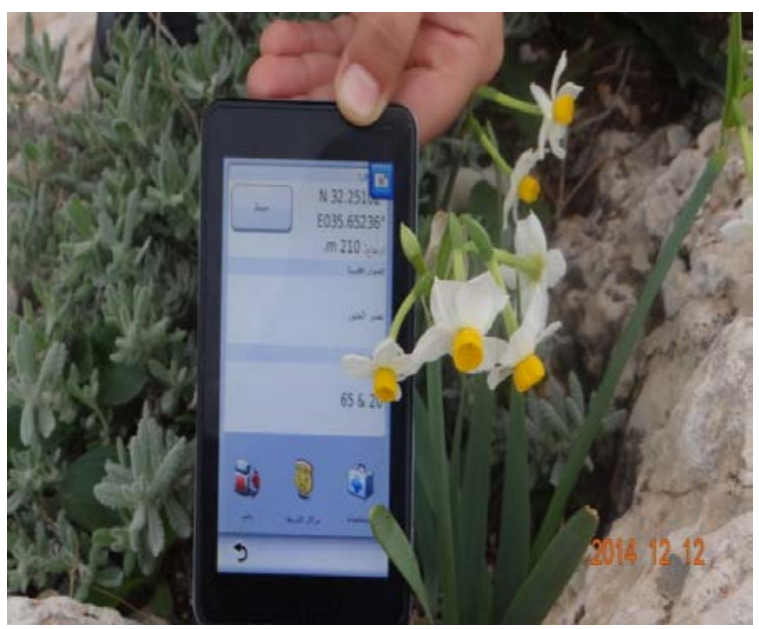

Figure 1. N. tazetta flowering plant in the wild at Ajloun-

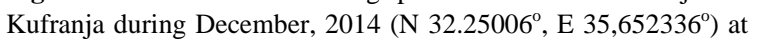
$210 \mathrm{~m}$ above sea level.

\subsection{Callus and Embryos induction}

To induce callus and embryos formation, sterilized segments of inner bulb scales of Narcissus tazetta were grown on (Murashig and Skoog, 1962) (MS) media premix (Duchefa Biochemiea: Murashige and Skoog media plus vitamins; Duchefa-Postbus 809,2003 RV Haarlem, Netherlands) supplemented with different concentrations $(0.5,1.0$ or $2.0 \mathrm{mg} / \mathrm{L})$ of 6-Benzylaminopurine (BAP) plus $0.1,0.4,1.0,2.0 \mathrm{mg} / \mathrm{L}$ of 1-Naphthaleneacetic acid (NAA) or 2,4-Dichlorophenoxyacetic acid (2,4-D). Next, the inner bulb scales were transferred to the growth room which consisted of the following physical conditions (the growth room temperature was $24 \pm 1^{\circ} \mathrm{C}$ under a $16 / 8$ (light/dark) and $45-50 \mu \mathrm{mol} / \mathrm{m}^{2} \mathrm{~s}$ irradiance or to full dark conditions) and maintained for five weeks. Data was taken for callus formation percentage in each treatment. Data showed that $1.0 \mathrm{mg} \mathrm{l}^{-1}$ of (BAP) with $2.0 \mathrm{mg} \mathrm{l}^{-1}$ (2,4-D) (Figure 2) was found to be the best formula for callus initiation (data is still under publication).

Next, different embryos induction media with different types and levels of growth regulators or carbon sources (sugars) were investigated. In the first experiment, different concentrations $(0.0,0.2,0.5,1.0,1.5$ or $2.0 \mathrm{mg} /$ $\mathrm{L})$ of growth regulators; (2iP, BAP, or Kinetin (KIN) were used. In the second experiment, different sugar types (sucrose, glucose or fructose) and levels $(0,10,30,40,50$ $\mathrm{g} / \mathrm{L})$ were added to MS callus induction media which contained $1.0 \mathrm{mg} \mathrm{l}-1$ of (BAP) plus $2.0 \mathrm{mg} \mathrm{l}-1$ (2,4-D). Each treatment in both experiments was replicated five (Petri dishes), each with 4 callus segments $(250 \mathrm{mg})$. Cultures were maintained in dark undergrowth room conditions where growth room temperature was $24 \pm 1^{\circ} \mathrm{C}$ while petri dish relative humidity was $90 \%$.
Data were collected after one month for callus fresh weight and number of embryos produced per each callus segment and number of regenerated shoots per non-each embryonic calli segment.

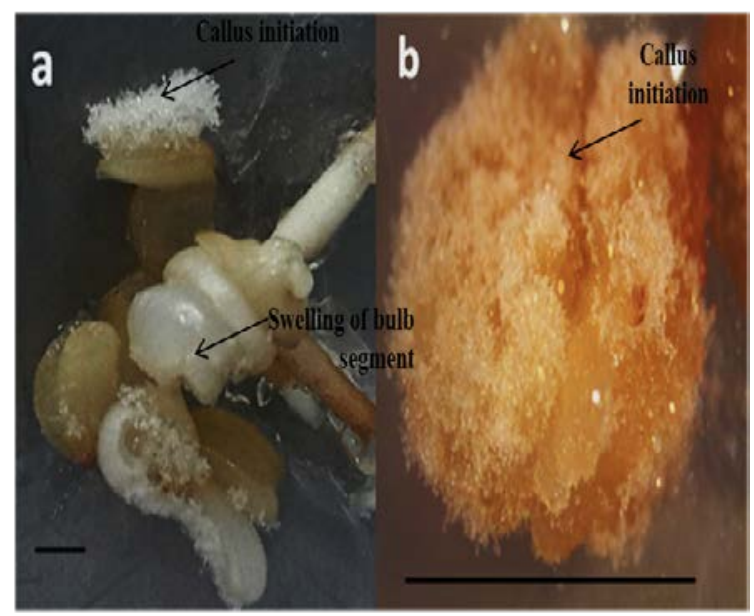

Figure 2. a) Start of callus initiation and swelling of $N$. tazetta explants cultured on MS media supplemented with $1.0 \mathrm{mg} / \mathrm{L} \mathrm{BAP}$ and 2.0 2,4-D, and maintained under dark for 5 weeks. b) Callus initiation of $N$. tazetta explants cultured on MS media supplemented with $1.0 \mathrm{mg} / \mathrm{L}$ BAP and 2.0 2,4-D, and maintained under dark for 7 weeks. Scale bar $=1.0 \mathrm{~cm}$.

\subsection{Shoot development from embryos}

Shoot development from the obtained embryos was experimented using MS media supplemented with $(0.0$, $0.2,0.5,1.0,1.5,2.0 \mathrm{mg} \mathrm{l}-1$ ) of different growth regulators; (2iP, BAP, or KIN) plus $30 \mathrm{~g}$ sucrose. However, to induce shoot development, cultures were transferred from dark into a daily regime of $24 \pm 1^{\circ} \mathrm{C}$ under a 16/8 (light/dark) photoperiod of $45-50 \mu \mathrm{mol} / \mathrm{m} 2 \mathrm{~s}$ irradiance. Numbers of regenerated shoots per segment of callus were recorded, and the percentage of germinated embryos was calculated. The regenerated shoots were subcultured into MS hormone-free media in $250 \mathrm{ml}$ Erlenmeyer flasks. After rooting, developed plants were ready for acclimatization.

\subsection{Acclimatization}

Before acclimatization, in vitro produced planlets were maintained in MS hormone-free media for (2, 4 and 6 weeks) to increase bublet size before being transferred to greenhouse conditions, as increasing bublet size would increase survival chances for the plantlets during acclimatization Ex vitro acclimatization was performed for plantlets with well-developed roots. The plantlets were taken out form the flasks then the agar was washed away from the roots under running tap water, then the plantlets were cultured into sterilized plastic cups $(5 \times 5 \mathrm{~cm})$ containing sterilized growing medium (peat: perlite mixture). Each cup was irrigated with distilled water every 3 days for 6 weeks. The potted plantlets were initially maintained inside the culture room conditions for 6 weeks and later transferred to green house $\left(33 \pm 1^{\circ} \mathrm{C}\right)$ conditions for 8 weeks, and data were recorded for survival rate.

All conducted treatments were arranged in a completely randomized design (CRD). Data were statistically analyzed using SPSS, and analysis of variance (ANOVA) was used to analyze the obtained results; means 
were separated with a probability level of 0.05 according to Tukey's honestly significant difference (HSD) test.

\section{Result and discussion}

\subsection{Effect of plant growth regulators on somatic embryos}

Embryo induction was observed after three weeks of inoculation of $N$. tazetta calli under concentrations of BAP and 2iP, while it took four weeks for embryos to appear in callus grown in KIN enriched media, while calli grown in the control treatment turned into brown and died. Using $2 \mathrm{iP}$ at $0.2 \mathrm{mg}^{-\mathrm{l}^{-1}}$ was significantly the most effective treatment as it resulted in the highest values of callus weight (1818.25 $\mathrm{mg})$, the number of somatic embryos (441.03/callus segment) and the number of regenerated shoots per non-embryonic calli (6.5) (Table 1, Figure 3). Meanwhile, high concentrations of $2 \mathrm{iP}$ had affected adversely callus growth, number of somatic embryos and regenerated shoots. Using $2 \mathrm{iP}$ for embryogenesis was reported in another study about Iris nigricans micropropagation, where embryos were successfully obtained in a medium supplemented with $1.0 \mathrm{mg} \mathrm{l}^{-1} 2 \mathrm{iP}$ as it yielded 2,686 embryos/g callus (Shibli and Ajlouni 2000). Similarly, Duquenne et al. (2006) in his study about "Zantedeschia hybrids reported that somatic embryos were regenerated into plantlets when cultured on MS medium supplemented with $1.0 \mathrm{mg} \mathrm{l}^{-1}$ 2iP. Meanwhile, our data showed that (KIN) at all used levels gave the least numbers of somatic embryos compared to the other plant growth regulators tested (Table 1). This result agrees with Shibli et al., (2012), who found that KIN was the least effective cytokinin for the production of embryogenic callus of Arum palaseitinum.
Table 1: Effect plant growth regulators type and level on embryonic callus weight, the approximate number of somatic embryos/ callus segment and the number of regenerated shoots per non-embryonic calli of $N$. tazetta cultured on MS media in dark at growth room conditions for 4 weeks.

\begin{tabular}{llll}
\hline $\begin{array}{l}\text { Growth } \\
\text { regulator } \\
(\mathrm{mg} / \mathrm{L})\end{array}$ & $\begin{array}{l}\text { Embryonic } \\
\text { callus weight } \\
(\mathrm{mg})\end{array}$ & $\begin{array}{l}\text { Approximate } \\
\text { number of } \\
\text { somatic } \\
\text { embryos/callus } \\
\text { segment }\end{array}$ & $\begin{array}{l}\text { Number of } \\
\text { regenerated } \\
\text { shoots/ } \\
\text { nonembryonic } \\
\text { calli segment }\end{array}$ \\
\hline BAP & & & \\
\hline $\mathrm{C}^{\mathrm{x}}$ & $0.0 \mathrm{~d}^{\mathrm{z}}$ & $0.0 \mathrm{~d}$ & $0.0 \mathrm{a}$ \\
0.2 & $1010 \mathrm{ab}$ & $262.6 \mathrm{ab}$ & $1.2 \mathrm{a}$ \\
0.5 & $1256 \mathrm{a}$ & $326.56 \mathrm{a}$ & $1.8 \mathrm{a}$ \\
1.0 & $710 \mathrm{c}$ & $184.6 \mathrm{c}$ & $0.8 \mathrm{a}$ \\
1.5 & $730 \mathrm{bc}$ & $189.8 \mathrm{bc}$ & $1.4 \mathrm{a}$ \\
2.0 & $546 \mathrm{c}$ & $141.96 \mathrm{c}$ & $1.8 \mathrm{a}$ \\
\hline $2 \mathrm{iP}$ & & & \\
\hline $\mathrm{C}^{\mathrm{x}}$ & $0.0 \mathrm{~d}^{\mathrm{z}}$ & $0.0 \mathrm{~d}$ & $0.0 \mathrm{c}$ \\
0.2 & $1818.25 \mathrm{a}$ & $441.03 \mathrm{a}$ & $6.5 \mathrm{a}$ \\
0.5 & $1195.8 \mathrm{~b}$ & $298.95 \mathrm{~b}$ & $4.4 \mathrm{~b}$ \\
1.0 & $1201.60 \mathrm{~b}$ & $300.4 \mathrm{~b}$ & $1.6 \mathrm{c}$ \\
1.5 & $952.50 \mathrm{bc}$ & $238.125 \mathrm{bc}$ & $1.33 \mathrm{c}$ \\
2.0 & $669.4 \mathrm{c}$ & $167.35 \mathrm{c}$ & $1.0 \mathrm{c}$ \\
\hline KIN & & & \\
\hline $\mathrm{C}^{\mathrm{x}}$ & $0.0 \mathrm{c}^{\mathrm{z}}$ & $0.0 \mathrm{c}$ & $0.0 \mathrm{~b}$ \\
0.2 & $558.75 \mathrm{~b}$ & $55.875 \mathrm{~b}$ & $0.0 \mathrm{~b}$ \\
0.5 & $754 \mathrm{ab}$ & $82.94 \mathrm{ab}$ & $2.4 \mathrm{ab}$ \\
1.0 & $670 \mathrm{ab}$ & $87.10 \mathrm{ab}$ & $0.4 \mathrm{~b}$ \\
1.5 & $825 \mathrm{ab}$ & $90.75 \mathrm{a}$ & $3.4 \mathrm{a}$ \\
2.0 & $900 \mathrm{a}$ & $99.0 \mathrm{a}$ & $1.6 \mathrm{ab}$ \\
\hline $\mathrm{C}$ Co & & & \\
\hline
\end{tabular}

${ }^{x}$ Control treatment represents hormone-free MS media. Each plant growth regulator was analyzed separately. ${ }^{\mathrm{z}}$ Means within columns having different letters are significantly different according to Tukey HSD at $\mathrm{P} \leq 0.05$.

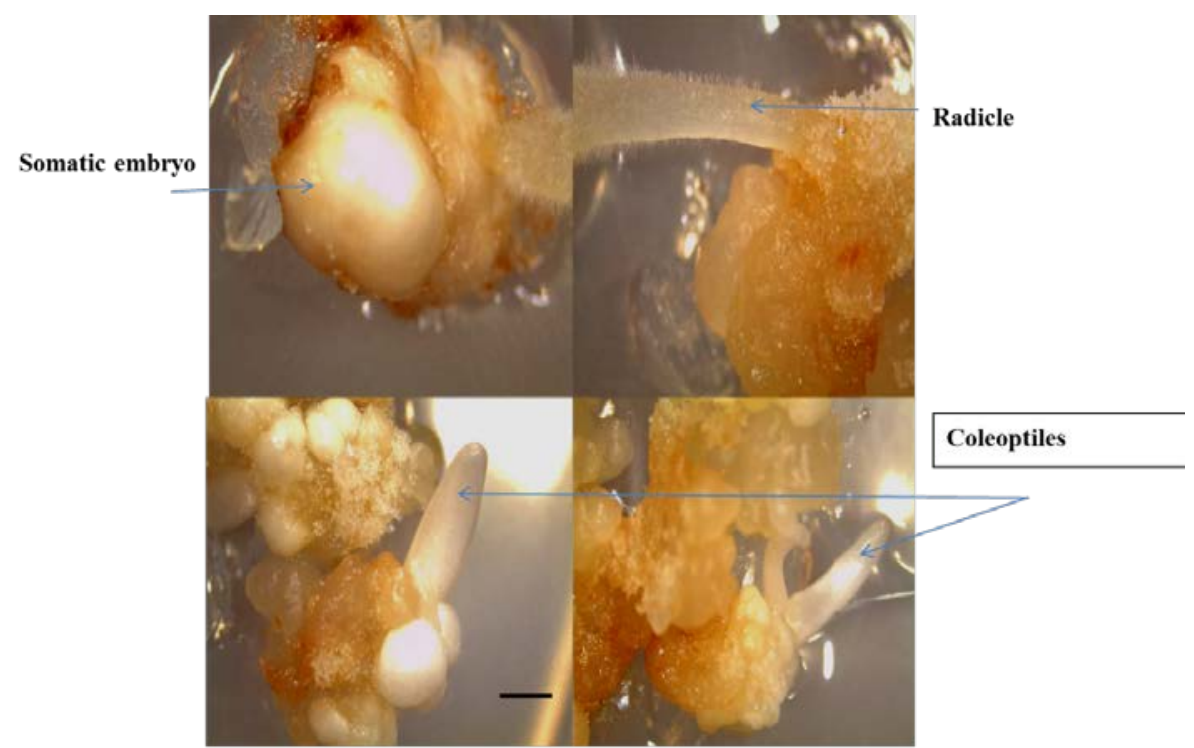

Figure 3. Germination of $N$. tazetta somatic embryos cultured on MS media supplemented with $0.2 \mathrm{mg} / \mathrm{L} 2 i \mathrm{P}$.. Scale bar $=0.50 \mathrm{~cm}$.

\subsection{The effect of different carbon sources on somatic embryos}

Our data revealed that sucrose at the level of $3 \% \mathrm{w} / \mathrm{v}$ was the best carbon source for N. tazetta when compared to fructose and glucose (Table 2). Meanwhile, $4 \%$ sucrose resulted in direct development of small bulblets and was not efficient for embryogenesis. On the other hand, glucose and fructose were not effective as a carbon source for embryos expression most callus formed became black with time and died (Table, 2). Sucrose was reported as the 
best as a carbon source for micropropagation in many plant species, as it is the most popular carbohydrate in the plant phloem (Murashige \& Skoog, 1962; Ahmad et al., 2007; Tahtamouni et al., 2016). Furthermore, in a study about strawberry, $6 \%$ sucrose was found superior not only for giving optimum embryo induction of embryonic culture but also a uniform embryo developmental stages compared to the other tested sugars ( glucose and fructose), (Gerdakaneh et al., 2009).

Table 2. Effect of carbon sources and levels on embryonic callus weight, number of somatic embryos, and number of regenerated shoots from non-embryonic calli of $N$. tazetta calli cultured on MS media supplemented with $0.2 \mathrm{mg} \mathrm{l}^{-1} \quad$ 2iP in dark at growth room conditions for 4 weeks.

\begin{tabular}{|c|c|c|c|}
\hline $\begin{array}{l}\text { Carbon } \\
\text { source (g/L) }\end{array}$ & $\begin{array}{l}\text { Embryonic } \\
\text { callus weight } \\
\text { (mg) }\end{array}$ & $\begin{array}{l}\text { Approximate } \\
\text { number of } \\
\text { somatic } \\
\text { embryos/callus } \\
\text { segment }\end{array}$ & $\begin{array}{l}\text { Number of } \\
\text { regenerated } \\
\text { shoots/ non- } \\
\text { embryonic calli } \\
\text { segment }\end{array}$ \\
\hline \multicolumn{4}{|l|}{ Sucrose } \\
\hline$C^{x}$ & $0.0^{*} c^{\mathrm{z}}$ & $0.0 \mathrm{c}$ & $0.0 \mathrm{c}$ \\
\hline 10 & $558.00 \mathrm{~b}$ & 14.2 bc & $3.20 \mathrm{ab}$ \\
\hline 30 & $1818.25 \mathrm{a}$ & $441.03 \mathrm{a}$ & $6.5 \mathrm{a}$ \\
\hline 40 & $520 \mathrm{~b}$ & $39.8 \mathrm{~b}$ & $4.4 \mathrm{a}$ \\
\hline 50 & $520 \mathrm{~b}$ & $16.7 \mathrm{bc}$ & $1.4 \mathrm{ab}$ \\
\hline \multicolumn{4}{|l|}{ Fructose } \\
\hline$C^{x}$ & $0.0 \mathrm{~b}^{\mathrm{z}}$ & $0.0 \mathrm{~b}$ & $0.0 \mathrm{a}$ \\
\hline 10 & 483 a & $7.7 \mathrm{a}$ & $0.4 \mathrm{a}$ \\
\hline 30 & $446 \mathrm{a}$ & $0.0 \mathrm{~b}$ & $0.0 \mathrm{a}$ \\
\hline 40 & $465 \mathrm{a}$ & $0.0 \mathrm{~b}$ & $0.0 \mathrm{a}$ \\
\hline 50 & $473.6 \mathrm{a}$ & $0.0 \mathrm{~b}$ & $0.0 \mathrm{a}$ \\
\hline \multicolumn{4}{|l|}{ Glucose } \\
\hline$C^{x}$ & $0.0 c^{z}$ & $0.0 \mathrm{~b}$ & $0.0 \mathrm{a}$ \\
\hline 10 & $289 \mathrm{~b}$ & $0.0 \mathrm{~b}$ & $0.2 \mathrm{a}$ \\
\hline 30 & $381 \mathrm{~b}$ & $13.5 \mathrm{a}$ & $0.8 \mathrm{a}$ \\
\hline 40 & $625 \mathrm{a}$ & $2.2 \mathrm{~b}$ & $0.0 \mathrm{a}$ \\
\hline 50 & $289 \mathrm{~b}$ & $0.8 \mathrm{~b}$ & $0.0 \mathrm{a}$ \\
\hline
\end{tabular}

${ }^{\mathrm{x}}$ Control treatment represents sugar free MS media $+0.2 \mathrm{mg} \mathrm{l}^{-1}$ 2iP. Each sugar type was analyzed separately. ${ }^{\mathrm{z}}$ Means within columns having different letters are significantly different according to Tukey HSD at $\mathrm{P} \leq 0.05$.

\subsection{Shoot developmentdevelopment from embryos}

The embryos started to germinate and developed into plantlets with shoots and roots after the subculture of embryonic callus into light conditions(Figure 4). Table 3 showed that $2 \mathrm{iP}$ at $0.5 \mathrm{mg} . \mathrm{l}^{-1}$ gave significantly the highest number of germinated shoots (191.99) and germination percentage (45.76\%) over the other concentrations or other plant growth regulators, while in BAP treatments, the highest number of germinated shoots (42.28) and germination percentage (16.3\%) were obtained on MS media supplemented with $0.2 \mathrm{mg} \mathrm{l}^{-1}$. Our data agree with, Lokhande et al. (2010) fiding on Sesuvium portulacastrum as the highest number of shoots, average shoot elongation, and percent shoot development per explant were observed on MS medium supplemented with $8.0 \mathrm{mg} \mathrm{l}^{-1} \quad 2 \mathrm{iP}$ followed by $4.50 \mathrm{mg} \mathrm{l}^{-1}$ BAP. Moreover, Zantedeschia hybrids somatic embryos developed into plantlets on basal media supplemented with $1.0 \mathrm{mg} \mathrm{l}^{-1}$ 2iP (Duquenne et al., 2006). On the other hand, Shibli et al., (2012) reported that the highest number of regenerated shoots from somatic embryos of $A$. palaestinum was achieved on MS media supplemented with $2.0 \mathrm{mg} \mathrm{l}^{-1} \mathrm{BAP}$

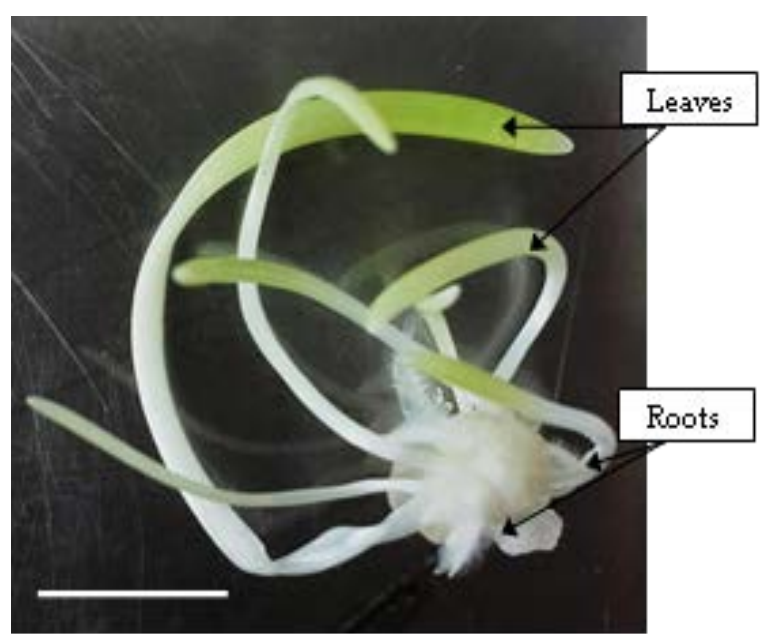

Figure 4. Regenerated $N$. tazetta plantlet from somatic embryos cultured on MS media supplemented with $0.5 \mathrm{mg} / \mathrm{L}$ of $2 \mathrm{iP}$, and maintained under growth room conditions of $24 \pm 1^{\circ} \mathrm{C}$ under a 16/8 (light/dark) photoperiod of $45-50 \mu \mathrm{mol} / \mathrm{m} 2 \mathrm{~s}$ irradiance and flask relative humidity of $90 \%$ for 4 weeks. Scale bar $=1.0 \mathrm{~cm}$.

Table 3: Effect of plant growth regulators type and level on the number of germinated shoots from somatic embryos and germination percentage of $N$. tazetta somatic embryos cultured on MS media for 4 weeks.

\begin{tabular}{lll}
\hline $\begin{array}{l}\text { Growth regulator } \\
(\mathrm{mg} / \mathrm{L})\end{array}$ & $\begin{array}{l}\text { Number of germinated } \\
\text { shoots from somatic } \\
\text { embryos }\end{array}$ & $\begin{array}{l}\text { Germination } \\
\text { percentage of } \\
\text { somatic embryos \% } \\
\text { (Number of } \\
\text { germinated } \\
\text { shoots/number of } \\
\text { somatic embryos \%) }\end{array}$ \\
\hline BAP & & \\
\hline $\mathrm{C}^{\mathrm{x}}$ & $0.0 \mathrm{c}$ & $0.0 \mathrm{~d}$ \\
0.2 & $42.28 \mathrm{a}$ & $16.3 \mathrm{a}$ \\
0.5 & $16.02 \mathrm{~b}$ & $4.95 \mathrm{~b}$ \\
1.0 & $5.28 \mathrm{c}$ & $2.76 \mathrm{bcd}$ \\
1.5 & $3.56 \mathrm{c}$ & $1.84 \mathrm{~cd}$ \\
2 & $5.11 \mathrm{c}$ & $3.36 \mathrm{bc}$ \\
\hline $2 \mathrm{iP}$ & & \\
\hline $\mathrm{C}^{\mathrm{x}}$ & $0.0 \mathrm{c}$ & $0.0 \mathrm{~d}$ \\
0.2 & $78.95 \mathrm{~b}$ & $29.44 \mathrm{~b}$ \\
0.5 & $191.99 \mathrm{a}$ & $45.76 \mathrm{a}$ \\
1.0 & $51.24 \mathrm{~b}$ & $16.32 \mathrm{c}$ \\
1.5 & $11.95 \mathrm{c}$ & $5.12 \mathrm{~d}$ \\
2 & $5.30 \mathrm{c}$ & $3.20 \mathrm{~d}$ \\
\hline KIN & & \\
\hline $\mathrm{C}^{\mathrm{x}}$ & $0.0 \mathrm{c}$ & $0.0 \mathrm{c}$ \\
0.2 & $0.0 \mathrm{c}$ & $0.0 \mathrm{c}$ \\
0.5 & $10.90 \mathrm{a}$ & $9.532 \mathrm{ab}$ \\
1.0 & $3.72 \mathrm{ab}$ & $3.70 \mathrm{bc}$ \\
1.5 & $5.08 \mathrm{ab}$ & $5.08 \mathrm{abc}$ \\
\hline
\end{tabular}

${ }^{\mathrm{x}}$ Control represents free hormone MS media supplemented with $30 \mathrm{~g} / \mathrm{L}$ sucrose. Each plant growth regulator was analyzed separately. ${ }^{\mathrm{z}}$ Means within columns having different letters are significantly different according to Tukey HSD at $\mathrm{P} \leq 0.05$. 


\subsection{Ex Vitro Acclimatization}

Our results showed that the period of incubating the plantlets on hormone-free MS media plus $30 \mathrm{~g}$ sucrose before acclimatization had positively affected bulb size measured after 5 weeks in the greenhouse conditions. Most plantlents incubated for 2 weeks in hormone-free MS media produced bulblets with approximately $0.5-0.6 \mathrm{~cm}$ in diameter and produced only a single leaf, while those inculcated for 4 weeks produced bulblets with $0.9-1.1 \mathrm{~cm}$ in diameter and 2 leaves. On the other hand plantlets inoculated for 6weeks produced bulblets with $1.4-1.6 \mathrm{~cm}$ in diameter and 3 leaves (Figure 5).

Meanwhile, most in vitro produced plants of $N$. tazetta L. showed excellent survival rate of $95 \%$ in growth room and $100 \%$ in the greenhouse. The acclimatized plants were normal and did not show any morphological abnormalities (Figure 6).

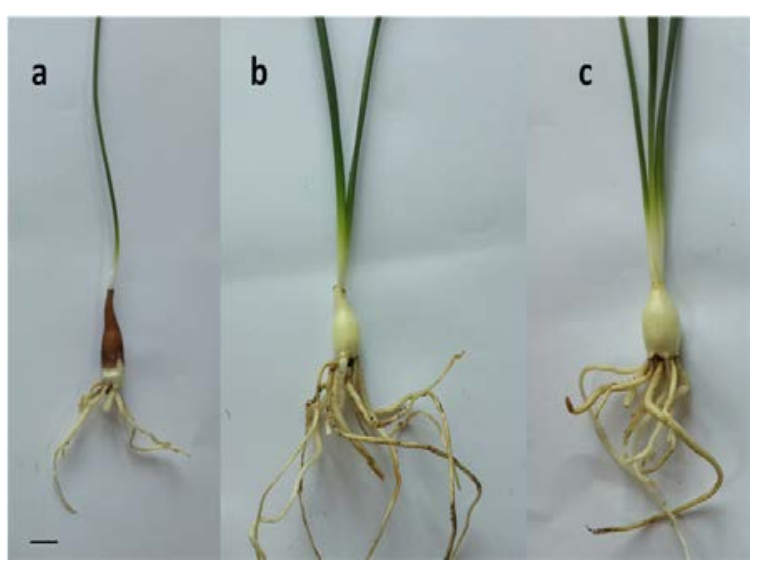

Figure 5. a) Bulblet of $N$. tazetta inculcated for 2 weeks on hormone-free MS media with approximately $0.5 \mathrm{~cm}$ diameter and single leaf. b) Bulblet of $N$. tazetta inculcated for 4 weeks on hormone-free MS media with approximately $1.0 \mathrm{~cm}$ diameter and two leaves. c) Bulblet of $N$. tazetta plant inculcated for 6 weeks on hormone-free MS media with approximately $1.6 \mathrm{~cm}$ diameter and three leaves. Scale bar $=1.0 \mathrm{~cm}$.

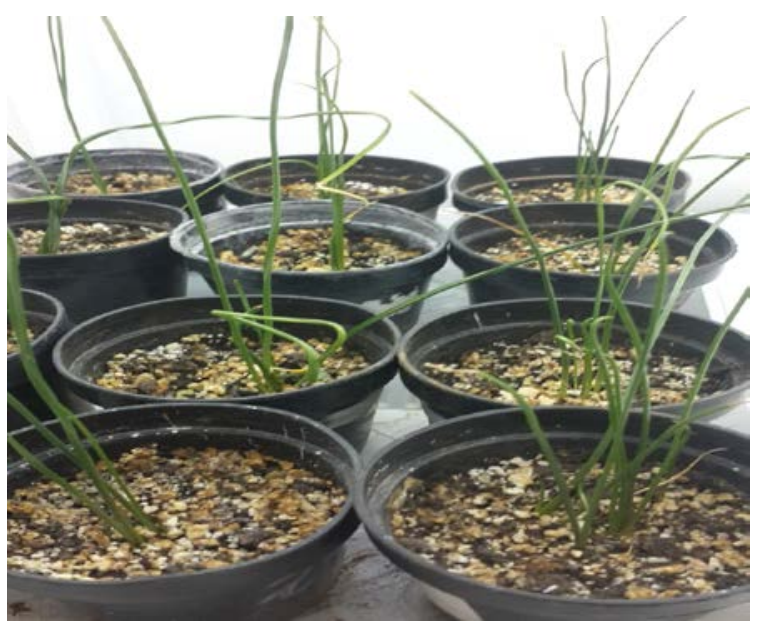

Figure 6. Successful acclimatization of $N$. tazetta plants maintained for 5 weeks on 1:1 peat perlite medium under greenhouse conditions and irrigated with tap water every 3 days with a $95 \%$ survival rate.

\section{Conclusion}

The current protocol could represent a successful tool for rapid micropropagation of $N$. tazetta via somatic embryogenesis using MS media $+0.2 \mathrm{mg} / \mathrm{L} 2 \mathrm{iP}+30 \mathrm{~g}$ sucrose. Meanwhile, adding $0.5 \mathrm{mg} / \mathrm{L} 2 \mathrm{iP}+30 \mathrm{~g}$ sucrose to the culture media was required for maximum shoot development from the resulting embryos. This protocol could be applied commercially to produce a high number of plants with high survival rates. Further studies can be done to produce flowering size bulbs that can flower in the current or next season. Also, more research can be conducted to induce production of medicinally important secondary metabolites including galantamine (GAL) in $N$. tazetta plant cells in vitro.

\section{References}

Ahmad T., Abbasi, N. A., Hafiz, I. A. and Ali, A. 2007. Comparison of sucrose and sorbitol as main carbon energy sources in micropropagation of peach rootstock GF-677. Pakistan Journal of Botany, 39(4): 1269-1275.

Al-Eisawi, D. M. 1998. Field guide to wild flower of Jordan and neighboring countries. Al-Rai, Amman, 296.

Alenizi A., Shibli R., Tahtamouni R., Al-Qudah T. S. 2020. In Vitro Propagation and Enhancement of Quercetins and Isorhamnetin Production in Wild Paronychia argentea L. Jordan Journal Pharmaceutical Sciences, 13(1): 65-75

Al-Qudah, T.S.; (2020). Discovering antimicrobial powers of some herbs used by Bedouin in the Jordanian Petra. Eco. Env. \& Cons., 26 (1). 433-440.

Al-Qudah T. S, R.A. Shibli, and F. Q. Alali. 2011. In vitro propagation and secondary metabolites production in wild germander (Teucrium polium L.). In Vitro Cellular and Developmental Biology - Plant. 47: 496-505.

Bores, G., Kosley, R. 1996. Galanthamine derivatives for the treatment of Alzheimer's disease. Drugs Future, 21(6):621-635).

Duquenne, B., Eeckhaut, T., Werbrouck, S., Van Huylenbroeck, J. 2006. In vitro somatic embryogenesis and plant development in Zantedeschia hybrids. Plant Cell, Tissue and Organ Culture, 87 (3): 329-331.

Gerdakaneh, M., Mozafari, A. A., Khalighi, A. 2009. The Effects of Carbohydrate Source and Concentration on Somatic Embryogenesis of Strawberry ( Fragaria $x$ ananassa Duch.). American-Eurasian Journal of Agricultural \& Environmental Sciences, 6(1): 76-80.

Khonakdari, M. R.; Rezadoost, H. Heydari, R.,Mirjalili, M. H. 2020. Effect of photoperiod and plant growth regulators on in vitro mass bulblet proliferation of Narcissus tazzeta L. (Amaryllidaceae), a potential source of galantamine. Plant Cell, Tissue and Organ Culture, 142:187-199.

Kumar, M., Singh, H., Shukla, A. K., Verma, P. C., Singh, P. K. 2013. Induction and establishment of somatic embryogenesis in elite Indian cotton cultivar (Gossypium hirsutum L. cv Khandwa2). Plant Signaling and Behavior, 8(10): 1-10.

Lokhande, V. H., Nikam, T. D., Ghane, S. G., Suprasanna, P. 2010. In vitro culture, plant regeneration and clonal behaviour of Sesuvium portulacastrum (L.) a prospective halophyte. Physiology and Molecular Biology of Plants, 16(2): 187-193.

Mostafa, S. E. Karam, N. S. Shibli, R. A. Alali, F.Q. 2010. Micropropagation and production of arbutin in oriental strawberry tree (Arbutus andrachne L.). Plant Cell, Tissue and Organ Culture, 103:111-121.

Murashige, T., Skoog, F. 1962. A revised medium for rapid growth and bio assays with tobacco tissue cultures. Physiologia Plantarum, 15(3): 473-497. 
RBG. Royal botanic garden. 2016. Jordanian habitats and flora. http://royalbotanicgarden.org/plants/narcissus-tazetta.

Shibli, R. A., and Ajlouni, M. M. 2000. Somatic embryogenesis in the endemic black iris. Plant Cell, Tissue and Organ Culture, 61(1): 15-21.

Shibli, R. A., Duwayri, M., Sawwan, J., Shatnawi, M., Al-Qudah, T. S. 2012. Regeneration via somatic embryogenesis of the endangered wild arum ( Arum palaestinum). In vitro Cell. Dev. Biol.-Plant. 48: 335-340.

Shibli, R. A., Sharaf, S. A., Kasrawi, M. A., and Al-Qudah, T. S. 2018. In Vitro Multiplication of the White Wormwood, Artemisia herba-alba asso. Jordan Journal of Biological Sciences, 11(3): 265271.
Stone, O. M. 1973. The elimination of viruses from Narcissus tazetta cv. Grand Soleil d'Or, and rapid multiplication of virusfree clones. Annals of Applied Biology, 73(1): 45-52.

Stone, O. M., Brunt, A. A., and Hollings, M. 1977. Methods, logistics and problems in the production, distribution and use of virus-free clones of Narcissus tazetta cv. Grand Soleil d'Or. Ann. Rep. Glasshouse Crops Res. Inst.

Tahtamouni, R., Shibli, R., Al-Abdallat, A.,Al-Qudah, T. 2016. Analysis of growth, oil yield, and carvacrol in Thymbra spicata L. after slow-growth conservation. Turkish Journal of Agriculture and Forestry, 40(2): 213-221 